\title{
Involvement of p38MAPK-ATF2 signaling pathway in alternariol induced DNA polymerase $\beta$ expression
}

\author{
JIMIN ZHAO $^{1 *}$, JUNFEN MA $^{2 *}$, JING LU $^{1}$, YANAN JIANG ${ }^{1}$, \\ YANYAN ZHANG $^{1}$, XIAOYAN ZHANG ${ }^{1}$, JUN ZHAO $^{3}$, HONGYAN YANG $^{1}$, \\ YOUTIAN HUANG ${ }^{1}$, MINGYAO ZHAO ${ }^{1}$, KANGDONG LIU $^{1}$ and ZIMING DONG ${ }^{1}$ \\ ${ }^{1}$ Department of Pathophysiology, School of Basic Medical Sciences, Zhengzhou University, Zhengzhou, Henan 450001; \\ ${ }^{2}$ Clinical Laboratory, The First Affiliated Hospital of Zhengzhou University, Zhengzhou, Henan 450052; \\ ${ }^{3}$ Department of Medical Oncology, Changzhi People's Hospital, Changzhi, Shanxi 046000, P.R. China
}

Received March 30, 2015; Accepted May 10, 2016

DOI: $10.3892 / \mathrm{ol} .2016 .4662$

\begin{abstract}
Base excision repair (BER) systems are important for maintaining the integrity of genomes in mammalian cells. Aberrant DNA bases or broken single strands can be repaired by BER. Consequently, DNA lesions, which may be caused by cancer and aging, have a close association with BER procedure. DNA polymerase $\beta$ ( $\operatorname{pol} \beta$ ) is a critical BER enzyme that can excise 5'-sugar phosphate prior to adding a nucleotide in the gap by its function as a DNA polymerase in the BER process. However, DNA pol $\beta$ is an error-prone DNA polymerase, and overexpressing pol $\beta$ increases the cellular spontaneous mutation rate. DNA pol $\beta$ overexpression has been identified in various human tumors, which implies that DNA pol $\beta$ overexpression has a close association with tumorigenesis. The present study showed that alternariol (AOH), a secondary product of a fungus that is found in grains and fruits, could cause DNA damage to NIH3T3 cells in a single cell gel electrophoresis, and that 2, 10 and $20 \mu \mathrm{M}$ AOH induced DNA pol $\beta$ overexpression in a dose-dependent manner. In the process, the level of phosphorylation of mitogen-activated protein kinase 14 (p38) mitogen-activated protein kinase (MAPK) and activating transcription factor 2 (ATF2) was increased. In addition, SB203580, a p38MAPK inhibitor, resulted in decreased DNA pol $\beta$ expression. Small hairpin RNA-p38MAPK had the same effect; notably, DNA pol $\beta$ expression was downregulated in p38MAPK knockdown cells. These data suggest that the
\end{abstract}

Correspondence to: Dr Kangdong Liu or Professor Ziming Dong, Department of Pathophysiology, School of Basic Medical Sciences, Zhengzhou University, 100 Kexue Avenue, Zhengzhou, Henan 450001, P.R. China

E-mail:kdliu@zzu.edu.cn

E-mail: dongzm@zzu.edu.cn

${ }^{*}$ Contributed equally

Key words: DNA polymerase $\beta$, alternariol, mitogen-activated protein kinase 14 mitogen-activated protein kinase, activating transcription factor 2
p38MAPK-ATF2 signaling pathway may be involved in DNA pol $\beta$ expression induced by $\mathrm{AOH}$.

\section{Introduction}

DNA polymerase $\beta(\operatorname{pol} \beta)$ is a highly conservative gene that is expressed in a low level and constant manner in mammalian animal cell cycles (1). DNA pol $\beta$ is not a major DNA polymerase in the DNA synthesis process, as it lacks intrinsic nuclease activities; however, the specific role of DNA pol $\beta$ is to participate in DNA base excision repair (BER) for maintaining genomic stability $(2,3)$. DNA pol $\beta$ is highly expressed when genomic DNA is attacked by alkylating agents, ultraviolet radiation or endogenous factors (4-6). However, overexpressed pol $\beta$ can also participate in DNA synthesis, which is an important mechanism of genetic instability due to the inaccuracy of its base pairing (7). Accumulating evidence also indicates that overexpressed pol $\beta$ is associated with cell transformation, tumor genesis and chemotherapeutic resistance (8-10). The overexpression of pol $\beta$ was identified in various human cancers, including esophageal carcinoma, gastric carcinoma and ovarian cancer $(8,9,11)$. Although the overexpression of pol $\beta$ is commonly observed in human cancers, the regulation of pol $\beta$ and its association with the signaling pathway remains elusive. Answers to these questions may benefit our understanding of tumorigenesis and provide information regarding novel ways for chemoprevention or chemotherapy.

A previous study showed that alternariol $(\mathrm{AOH})$, a source of DNA damage, could induce DNA pol $\beta$ expression through the protein kinase A (PKA) signal transduction pathway, and that the PKA inhibitor, H89, can partly block pol $\beta$ expression (12). In addition, mitogen-activated protein kinase 14 (p38) mitogen-activated protein kinase (MAPK) was activated by $\mathrm{AOH}$ in NIH3T3 cells (12). Activating transcription factor 2 (ATF2) is one of the downstream molecules of the MAPK signal pathway and can be activated by p38MAPK and mitogen-activated protein kinase 8 (JNK) $(13,14)$. ATF2 is a member of ATF or cAMP-responsive element binding protein (CREB) family, which contains the basic/leucine zipper motifs (bZIP) and can bind to cAMP-responsive elements (CREs) $(15,16)$. The DNA pol $\beta$ promoter also contains the CRE sequence (17). Therefore 
the MAPK-ATF2 signaling pathway may be involved in pol $\beta$ expression. In the present study, DNA damage was found to be associated with pol $\beta$ expression induced by alternariol $(\mathrm{AOH})$, and p38MAPK and ATF2 activation was detected. When cells were pretreated with the p38MAPK inhibitor SB203580, the level of phosphorylation of p38MAPK and ATF2 was decreased, and the expression of pol $\beta$ was reduced. This finding is consistent with the result that pol $\beta$ expression decreased in NIH3T3 cells with p38MAPK knockdown.

\section{Materials and methods}

Chemicals and reagents. AOH and dimethyl sulfoxide (DMSO) were purchased from Sigma-Aldrich, Inc. (St. Louis, MO, USA). Anti-phosphorylated (p-)p38MAPK [rabbit polyclonal immunoglobulin G (IgG); catalog no., sc-17852-R], anti-DNA pol $\beta$ (goat polyclonal IgG; catalog no., sc-5927), anti- $\beta$-actin (mouse monoclonal; catalog no., sc-47778) and anti- $\alpha$-tubulin (mouse monoclonal; catalog no., sc-23948) primary antibodies and goat anti-rabbit IgG-horseradish peroxidase (HRP) (catalog no., sc-2004), rabbit anti-mouse IgG-HRP (catalog no., sc-358914) and donkey anti-goat IgG-HRP (sc-2020) secondary antibodies were obtained from Santa Cruz Biotechnology, Inc. (Dallas, TX, USA). Anti-p-ATF2 (rabbit polyclonal; catalog no., CST9225) was obtained from Cell Signaling Technology, Inc. (Danvers, MA, USA). RPMI-1640 and fetal bovine serum (FBS) was purchased from Thermo Fisher Scientific, Inc. (Waltham, MA, USA). SB203580 and the Enhanced Chemiluminescence (ECL) Plus Detection kit were purchased from Beyotime Institute of Biotechnology (Haimen, China). Reagents for protein concentration analysis were obtained from Bio-Rad Laboratories, Inc. (Hercules, CA, USA).

Cell culture. The NIH3T3 cell line was obtained from China Center for Type Culture Collection (Wuhan, China). The cells were cultured in RPMI-1640 with $10 \%$ FBS, 100 units (U)/ml penicillin and $100 \mu \mathrm{g} / \mathrm{ml}$ streptomycin at $37^{\circ} \mathrm{C}$ and $5 \% \mathrm{CO}_{2}$ in a humidified incubator.

Comet assay. To detect the DNA damage of NIH3T3 cells induced by various concentrations of $\mathrm{AOH}$, an alkaline comet assay was performed. Cells $\left(2 \times 10^{6}\right)$ were cultured in $10-\mathrm{cm}$ dishes for $\sim 48 \mathrm{~h}$. When the cells reached $80 \%$ confluence, they were treated with 2,10 or $20 \mu \mathrm{M} \mathrm{AOH}$ or DMSO for $2 \mathrm{~h}$. Fully frosted slides were then coated with $1 \%$ normal melting agarose at $45^{\circ} \mathrm{C}$ as a base layer, and were solidificated at $4^{\circ} \mathrm{C}$ for $10 \mathrm{~min}$. The cells were suspended in $0.8 \%$ low melting agarose at $37^{\circ} \mathrm{C}$. This suspension was pipetted over the base layer, which was covered with a cover slip immediately. The slides were placed at $4^{\circ} \mathrm{C}$ for $10 \mathrm{~min}$, and then the cover slips were removed. The slides were kept in the lysis buffer ( $\mathrm{pH} \mathrm{10)}$ at $4^{\circ} \mathrm{C}$ for $1 \mathrm{~h}$ and transferred into electrophoretic running buffer ( $\mathrm{pH} \mathrm{13)} \mathrm{for} \mathrm{unwinding} \mathrm{for} 30 \mathrm{~min}$. Electrophoresis was performed in the same buffer for $20 \mathrm{~min}$ at $0.8 \mathrm{v} / \mathrm{cm}$. Subsequently, the slides were washed with neutralizing buffer and stained with ethidium bromide $(20 \mu \mathrm{g} / \mathrm{ml})$ for $5 \mathrm{~min}$, and washed with cold saline. Finally, the glycerine buffer was placed on the slides in a dropwise manner and cover slips were placed on top. The slides were visualized using a fluorescence microscope (Olympus, Tokyo, Japan).
Western blotting. Cells $\left(2 \times 10^{6}\right)$ were cultured in $10-\mathrm{cm}$ dishes for $\sim 48 \mathrm{~h}$. When the cells reached $80 \%$ confluence, they were treated with various concentrations $(2,10$ or $20 \mu \mathrm{M})$ of $\mathrm{AOH}$, cells were lysed in radioimmunoprecipitation assay buffer [50 mm Tris/ $\mathrm{HCl}, \mathrm{pH}$ 7.5, $150 \mathrm{mM} \mathrm{NaCl}, 1 \mathrm{mM}$ ethylenediaminetetraacetic acid, $1 \mathrm{mM} \mathrm{Na} \mathrm{VO}_{4}, 0.1 \%$ sodium dodecyl sulfate (SDS), $1 \%$ (v/v) NP-40, 1 mM NaF, containing complete protease and phosphatase inhibitor cocktail (Roche Diagnostics, Indianapolis, IN, USA)], and supernatants were collected by centrifugation at $21,341 \mathrm{x} \mathrm{g}$ for $20 \mathrm{~min}$. Cell lysate $(50 \mu \mathrm{g})$ was separated on a $10 \%$ SDS-polyacrylamide gel and transferred to a polyvinylidene fluoride membrane. After blocking with $5 \%$ nonfat dried milk for $1 \mathrm{~h}$, the membrane was incubated with a primary antibody at $4^{\circ} \mathrm{C}$ overnight (anti-p-p38MAPK, 1:200 dilution; anti-p-ATF2, 1:1,000 dilution; anti-DNA pol $\beta$, 1:200 dilution; anti- $\alpha$-tubulin and anti- $\beta$-actin, 1:1,000 dilution). IgG-HRP secondary antibodies were incubated for $2 \mathrm{~h}$ at room temperature. Protein bands were visualized using the ECL Plus Detection kit. The bands were subjected to densitometry for quantitative analysis using Quantity One software (Bio-Rad Laboratories, Inc.).

p38MAPK-small hairpin RNA (shRNA) lentiviral vector. The pLKO.1, pCMV-dR8.2 and pCMV-VSVG vectors were kindly provided by Dr Zigang Dong (The Hormel Institute, Austin, MN, USA). The lentivirus-based shRNA-expressing vectors was a pLKO.1 back bone with the human U6 promoter driving RNA polymerase III transcription. The puromycin resistance marker encoded in pLKO.1 allows for convenient stable selection. The shRNA sequence of p38MAPK (5'-ATA CATTCGGCTGACATAATT-3') was cloned into the lentiviral shRNA-expressing vectors at the AgeI and EcoRI restriction sites (New England Biolabs Ltd., Beijing, China), and were confirmed by direct DNA sequencing (Genewiz Inc., Beijing, China).

The lentiviral vector containing the p38MAPK-shRNA, a packaging vector (pCMV-dR8.2) and an envelope vector (pCMV-VSVG) were co-transfected into 293T cells using Lipofectamine 2000 (Invitrogen; Thermo Fisher Scientific, Inc.). After $24 \mathrm{~h}$ and $48 \mathrm{~h}$, the viral supernatants were harvested and added to the NIH3T3 cells. Subsequently, $2 \mathrm{mg} / \mathrm{ml}$ puromycin was used to select the stably infected cells.

Statistics. All results were presented as mean \pm standard deviation of the mean. Statistics analysis was performed using analysis of variance in SPSS 11.0 software (SPSS, Inc., Chicago, IL, USA). $\mathrm{P}<0.05$ was considered to indicate statistical significance.

\section{Results}

AOH-induced DNA damage. To investigate the DNA toxic effect of AOH on NIH3T3 cells, a comet assay was conducted. NIH3T3 cells were treated with DMSO or 2,10 or $20 \mu \mathrm{M}$ $\mathrm{AOH}$ for $2 \mathrm{~h}$. The results of single cell gel electrophoresis showed that 10 and $20 \mu \mathrm{M}$ AOH increased the length and area of comet tails, a phenotype of DNA damage (Fig. 1A). DNA $\operatorname{pol} \beta$ is a polymerase that participates in the repair of DNA strand breaks. Thus, the present study investigated whether or not DNA pol $\beta$ was activated in DNA damage induced by 


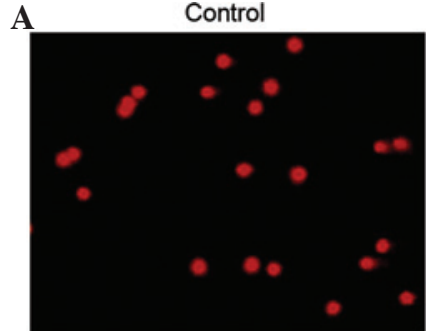

$10 \mu \mathrm{M} \mathrm{AOH}$
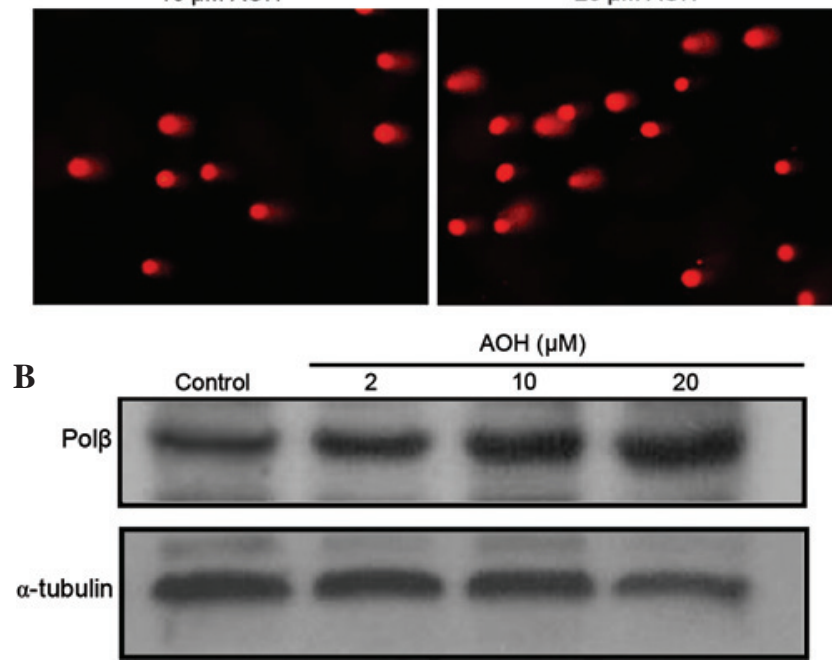

Figure 1. AOH caused DNA damage and increased pol $\beta$ expression. NIH3T3 cells were treated with 2,10 or $20 \mu \mathrm{M}$ of $\mathrm{AOH}$ or dimethyl sulfoxide for $2 \mathrm{~h}$ (A) Comet assay indicated that the area of cell tails increased with 10 and $20 \mu \mathrm{M}$ AOH treatment compared with control. (B) In addition, the expression level of pol $\beta$ increased with increasing $\mathrm{AOH}$ concentration in western blotting. $\mathrm{AOH}$, alternariol; pol $\beta$, DNA polymerase $\beta$.

AOH. NIH3T3 cells were treated with $\mathrm{AOH}$. Western blotting was performed to determine pol $\beta$ protein level with various doses of $\mathrm{AOH}$ treatment. The results showed that the protein level of pol $\beta$ protein increased in a dose-dependent manner with $\mathrm{AOH}$ treatment compared with the control (Fig. 1B).

AOH-induced activation of p38MAPK and ATF2. Western blotting was used to determine the level of p38MAPK phosphorylation after $\mathrm{AOH}$ treatment at various doses and time points. Results showed that the activation of p38MAPK increased in a dose-dependent manner $(2 \mu \mathrm{M}$ $\mathrm{AOH}$ group, $\mathrm{P}=0.002$ vs. control group; $10 \mu \mathrm{M} \mathrm{AOH}$ group, $\mathrm{P}<0.001$ vs. control group; $20 \mu \mathrm{M} A O H$ group, $\mathrm{P}<0.001$ vs. control group) (Fig. 2A). The level of p38MAPK phosphorylation was highest when the NIH3T3 cells were treated with $10 \mu \mathrm{M} \mathrm{AOH}$ at $2 \mathrm{~h}(1 \mathrm{~h}$ group, $\mathrm{P}<0.001$ vs. control group; $2 \mathrm{~h}$ group, $\mathrm{P}<0.001$ vs. control group; $4 \mathrm{~h}$ group, $\mathrm{P}<0.001$ vs. control group) (Fig. 2B). SB203580, an inhibitor of p38MAPK, can effectively block the phosphorylation of p38MAPK. To determine whether AOH induces the phosphorylation of p38MAPK, the NIH3T3 cells were pretreated with $10 \mu \mathrm{M} \mathrm{SB} 203580$ for $1 \mathrm{~h}$, then treated with $10 \mu \mathrm{M} \mathrm{AOH}$. Western blot analysis showed a significant decrease of p38MAPK phosphorylation in SB203580 pretreatment group compared with the $\mathrm{AOH}-$ only treated group (SB203580+AOH group, $\mathrm{P}=0.013$ vs. control group; $\mathrm{AOH}$ group, $\mathrm{P}<0.001$ vs. control group) (Fig. 2C).
ATF2 is a transcription factor that can be activated by p38MAPK. Activated p38MAPK can phosphorylate ATF2 in the cell stress response process. To further identify the activation of ATF2 evoked by phosphorylated p38MAPK with $\mathrm{AOH}$ treatment, western blotting was performed to determine the level of ATF2 phosphorylation when NIH3T3 cells were treated with various doses of $\mathrm{AOH}$ at different time points. The results were consistent with the change of p38MAPK phosphorylation, which revealed that phosphorylation occurred in a dose-dependent manner and that the peak activation of ATF2 occurred at the same time as p38MPAK (in dose groups, $2 \mu \mathrm{M}$ AOH group, $\mathrm{P}=0.384$ vs. control group; $10 \mu \mathrm{M}$ AOH group, $\mathrm{P}=0.001$ vs. control group; $20 \mu \mathrm{M} \mathrm{AOH}$ group, $\mathrm{P}<0.001 \mathrm{vs}$. control group; in time groups, $1 \mathrm{~h}$ group, $\mathrm{P}<0.001$ vs. control group; 2 h group, $\mathrm{P}<0.001$ vs. control group; $4 \mathrm{~h}$ group, $\mathrm{P}=0.001$ vs. control group) (Fig. $2 \mathrm{~A}$ and $\mathrm{B}$ ). Furthermore, the level of ATF2 phosphorylation decreased in the SB203580 pretreatment group compared with the AOH-only treated group ( $\mathrm{SB} 203580+\mathrm{AOH}$ group, $\mathrm{P}=0.057$ vs. control group; $\mathrm{AOH}$ group, $\mathrm{P}<0.001$ vs. control group) (Fig. 2C).

Subsequently, the AOH-induced phosphorylation of p38MAPK and ATF2 was assessed for associations with the expression level of pol $\beta$. Pol $\beta$ expression was observed in western blotting assays when cells were pretreated with SB203580, an inhibitor of p38MAPK. The expression level of pol $\beta$ was found to decrease in the pretreatment group compared with the $\mathrm{AOH}$ stimulation group (Fig. 3).

To further verify the role of the p38MAPK-ATF2 pathway in pol $\beta$ expression, p38MAPK knockdown was performed by lentiviral shRNA transfection. The results of the western blotting showed that p38MAPK knockdown was associated with the reduced phosphorylation of ATF2 and the decreased expression of pol $\beta$ (Fig. 4).

\section{Discussion}

The present study investigated the role of the signaling transduction pathway of p38MAPK and ATF2 in the expression of the DNA pol $\beta$ gene, induced by $\mathrm{AOH}$. When this signaling pathway was blocked, the level of expression of DNA pol $\beta$ decreased. In a previous study, $\mathrm{AOH}$ was indicated to induce the overexpression of DNA pol $\beta$ through the activation of the PKA-CREB pathway in NIH3T3 cells (12); however, when H89 (18), a inhibitor of PKA, was used to pretreat the cells, DNA pol $\beta$ expression was observed to partly decrease, rather than entirely. The results of the present study suggest that p38MAPK-ATF2 may also be involved in DNA pol $\beta$ expression when NIH3T3 cells are stimulated by AOH.

MAPK family members can respond to diverse stimuli, and p38MAPK, one of four subgroups in the MAPK family, is important for cellular essential activity (19). p38MAPK can phosphorase numerous transcription factors and regulate gene expression. ATF2 is one of the downstream molecules of p38MAPK that belongs to the ATF/CREB transcription factor family and can recognize and bind to the CRE sequence as dimers in the promoters of certain genes (15). The DNA pol $\beta$ gene promoter includes a CRE site with the 8 bp palindromic sequence TGACGTCA. In the study by Kreideweiss et al (20), $\mathrm{Ca}^{2+}$-mediated intracellular signaling pathways events in human peripheral blood mononuclear cells (PBMCs) activated 
A

$\mathbf{A}$
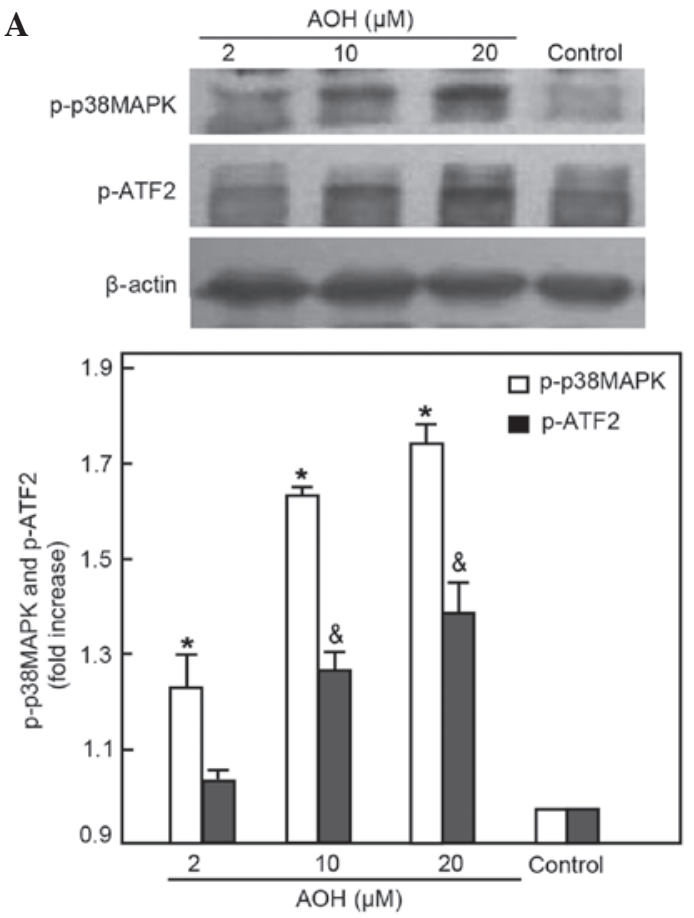

B
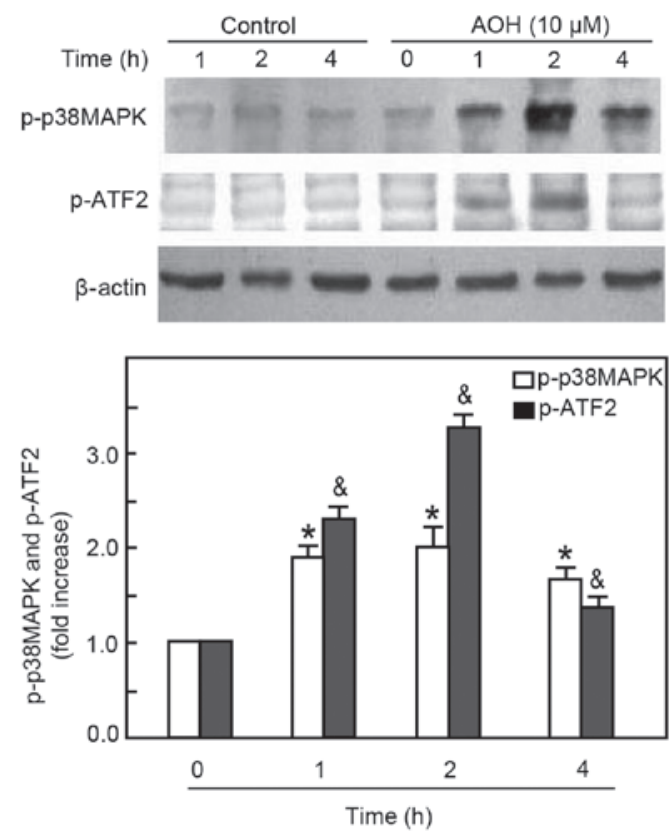

C
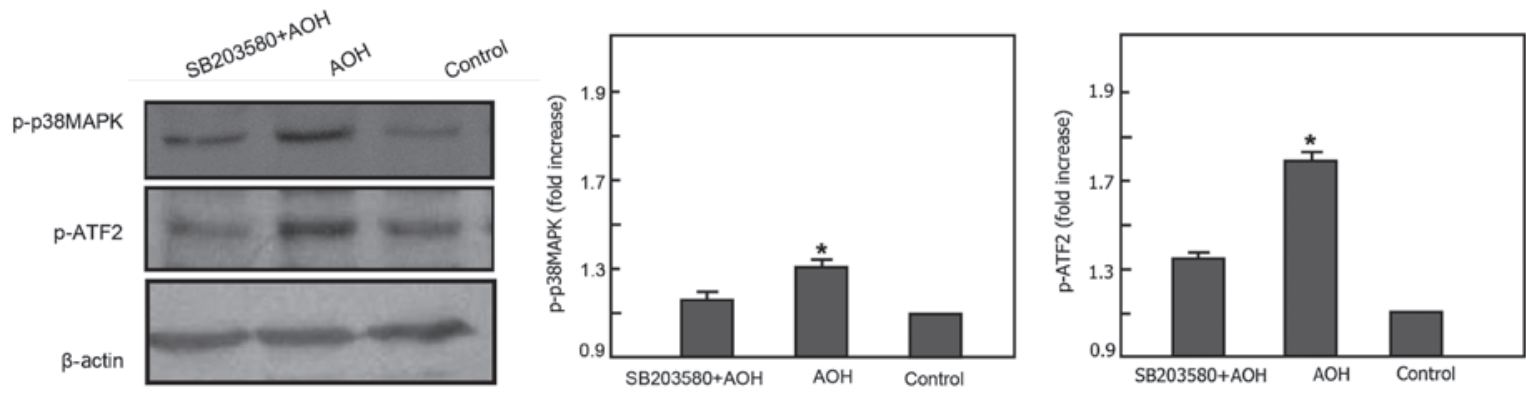

Figure 2. AOH-induced p38MAPK and ATF2 activation. NIH3T3 cells were treated with indicated dose of AOH for $2 \mathrm{~h}$. (A) Phosphorylation levels of p38MAPK and ATF2 were detected by western blotting. (B) Cells were treated with $20 \mu \mathrm{M} \mathrm{AOH}$ for the indicated time, and the levels of phosphorylated p38MAPK and ATF2 were measured by western blotting. (C) Cells were pretreated with SB203580 $1 \mathrm{~h}$ prior to $20 \mu \mathrm{M}$ AOH exposure. p38MAPK and ATF2 phosphorylation was indicated by western blotting. Data are shown as means \pm standard deviation of values from triplicate experiments, the symbols $(*)$ and $(\&)$ indicate a significant $(\mathrm{P}<0.05)$ change in expression compared with the respective dimethyl sulfoxide treated control. AOH, alternariol; p38MAPK, mitogen-activated protein kinase 14 mitogen-activated protein kinase; ATF2, activating transcription factor 2; p-p38MAPK, phosphorylated p38MAPK; p-ATF2, phosphorylated ATF2.

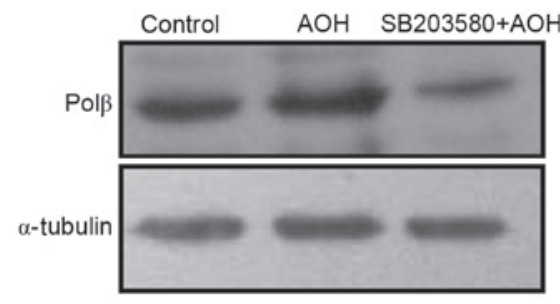

Figure 3. p38MAPK inhibitor SB203580 decreased the expression of pol $\beta$. NIH3T3 cells were pretreated with SB203580 $(10 \mu \mathrm{M})$ for $1 \mathrm{~h}$ followed by $\mathrm{AOH}(20 \mu \mathrm{M})$ for $24 \mathrm{~h}$, or only treated by $\mathrm{AOH}(20 \mu \mathrm{M})$. Cell extract was used to determine the expression level of pol $\beta$ by western blotting. p38MAPK, mitogen-activated protein kinase 14 mitogen-activated protein kinase; pol $\beta$, DNA polymerase $\beta$.

MAPK cascades and phosphorylated transcription factor ATF2. The study found that ATF2 and CREB can bind to the CRE site of the DNA pol $\beta$ promoter and ATF2 contributes to the expression of the pol $\beta$ gene (20). However, p38 was not the kinase mediating ATF2 phosphorylation upon stimulation of primary PBMCs with $\mathrm{Ca}^{2+}$, as the induction of ATF2

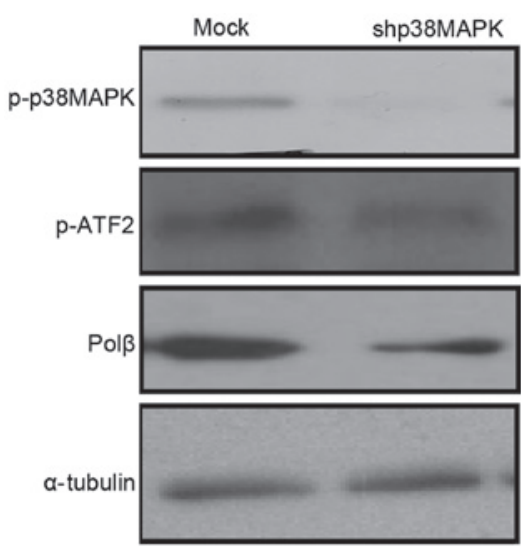

Figure 4. p38MAPK knockdown reduced ATF2 phosphorylation and pol $\beta$ expression. Lentiviral small hairpin RNA expressing vectors targeting p38MAPK were constructed and transfected into NIH3T3 cells after finishing virus packing. The p38MAPK knockdown cell line was obtained by puromycin selection. The level of p38MAPK and ATF2 phosphorylation and the expression of pol $\beta$ were measured by western blotting. p38MAPK, mitogen-activated protein kinase 14 mitogen-activated protein kinase; ATF2, activating transcription factor 2 ; pol $\beta$, DNA polymerase $\beta$; p-p38MAPK, phosphorylated p38MAPK; p-ATF2, phosphorylated ATF2. 
phosphorylation was not affected by the presence of the $\mathrm{p} 38 \mathrm{a}$ inhibitor SB203580 at $10 \mu \mathrm{M}$ concentrations (20). This result is in contrast to the results of the present study. In the current study, AOH stimulated ATF2 activation, followed by p38 phosphorylation. Chyan et al (21) identified a novel ATF2 isoform, which encodes a $60-\mathrm{kDa}$ protein with an incomplete $\mathrm{N}$-terminal domain, and a novel $\mathrm{C}$-terminal region, but an intact bZIP domain, which binds to the human pol $\beta$ CRE and functions as a repressor of the cloned human pol $\beta$ promoter in 293 cells. Interestingly, the results of the study by Faumont et al (22) indicated that nuclear factor- $\kappa \mathrm{B}$ activation participates in the overexpression of DNA pol $\beta$ in Epstein-Barr virus-immortalized B cells. Therefore, the data additionally indicated that the expression of DNA pol $\beta$ is regulated by multiple factors and pathways in cells, and that that expression is stimuli, cell type and context dependent (22). This mobile regulation of DNA pol $\beta$ also implies that its overexpression is important for working against DNA damage. The expression of DNA pol $\beta$ is easily adjusted when the intracellular or extracellar environment changes through a corresponding pathway, which helps to maintain genomic stability.

In summary, the present study indicates that p38MAPK phosphorylation and the activation of its downstream molecule, ATF2, is important for mediating DNA pol $\beta$ expression following treatment with $\mathrm{AOH}$ in NIH3T3 cells. However, it may be worthwhile to additionally study a suitable method that could be used to regulate the balance of DNA pol $\beta$ expression for genomic stability.

\section{Acknowledgements}

The present study was supported by grants from National Science Foundation in China, Beijing, China (grant nos. 81372269 and 81472324), and the Natural Science Foundation of the Henan province of China, Zhengzhou, China (grant no. 14A310011).

\section{References}

1. Zmudzka BZ, Fornace A, Collins J and Wilson SH: Characterization of DNA polymerase beta mRNA: Cell-cycle and growth response in cultured human cells. Nucleic Acids Res 16: 9587-9596, 1988.

2. Kim YJ and Wilson DM III: Overview of base excision repair biochemistry. Curr Mol Pharmacol 5: 3-13, 2012.

3. Kidane D, Dalal S, Keh A, Liu Y, Zelterman D and Sweasy JB: DNA polymerase beta is critical for genomic stability of sperm cells. DNA Repair (Amst) 10: 390-397, 2011.

4. Cabelof DC, Raffoul JJ, Yanamadala S, Guo Z and Heydari AR: Induction of DNA polymerase beta-dependent base excision repair in response to oxidative stress in vivo. Carcinogenesis 23: $1419-1425,2002$

5. Horton JK, Baker A, Berg BJ, Sobol RW and Wilson SH: Involvement of DNA polymerase beta in protection against the cytotoxicity of oxidative DNA damage. DNA Repair (Amst) 1: $317-333,2002$
6. Servant L, Cazaux C, Bieth A, Iwai S, Hanaoka F and Hoffmann JS: A role for DNA polymerase beta in mutagenic UV lesion bypass. J Biol Chem 277: 50046-50053, 2002.

7. Chan K, Houlbrook S, Zhang QM, Harrison M, Hickson ID and Dianov GL: Overexpression of DNA polymerase beta results in an increased rate of frameshift mutations during base excision repair. Mutagenesis 22: 183-188, 2007.

8. Albertella MR, Lau A and O'Connor MJ: The overexpression of specialized DNA polymerases in cancer. DNA Repair (Amst) 4: 583-593, 2005.

9. Tan XH, Zhao M, Pan KF, Dong Y, Dong B, Feng GJ, Jia G and $\mathrm{Lu}$ YY: Frequent mutation related with overexpression of DNA polymerase beta in primary tumors and precancerous lesions of human stomach. Cancer Lett 220: 101-114, 2005.

10. Yang J, Parsons J, Nicolay NH, Caporali S, Harrington CF, Singh R, Finch D, D'Atri S, Farmer PB, Johnston PG, et al: Cells deficient in the base excision repair protein, DNA polymerase beta, are hypersensitive to oxaliplatin chemotherapy. Oncogene 29: 463-468, 2010.

11. Dong ZM, Zheng NG, Wu JL, Li SK and Wang YL: Difference in expression level and localization of DNA polymerase beta among human esophageal cancer focus, adjacent and corresponding normal tissues. Dis Esophagus 19: 172-176, 2006.

12. Zhao J, Liu K, Lu J, Ma J, Zhang X, Jiang Y, Yang H, Jin G, Zhao G, Zhao M and Dong Z: Alternariol induces DNA polymerase $\beta$ expression through the PKA-CREB signaling pathway. Int J Oncol 40: 1923-1928, 2012.

13. Vlahopoulos SA, Logotheti S, Mikas D, Giarika A, Gorgoulis V and Zoumpourlis V: The role of ATF-2 in oncogenesis. Bioessays 30: 314-327, 2008.

14. Gupta S, Campbell D, Dérijard B and Davis RJ: Transcription factor ATF2 regulation by the JNK signal transduction pathway. Science 267: 389-393, 1995.

15. De Cesare D and Sassone-Corsi P: Transcriptional regulation by cyclic AMP-responsive factors. Prog Nucleic Acid Res Mol Biol 64: 343-369, 2000.

16. Green TA, Alibhai IN, Unterberg S, Neve RL, Ghose S, Tamminga CA and Nestler EJ: Induction of activating transcription factors (ATFs) ATF2, ATF3, and ATF4 in the nucleus accumbens and their regulation of emotional behavior. J Neurosci 28: 2025-2032, 2008.

17. Widen SG and Wilson SH: Mammalian beta-polymerase promoter: Large-scale purification and properties of ATF/CREB palindrome binding protein from bovine testes. Biochemistry 30: 6296-6305, 1991

18. Chijiwa T, Mishima A, Hagiwara M, Sano M, Hayashi K, Inoue $T$, Naito $K$, Toshioka $T$ and Hidaka $H$ : Inhibition of forskolin-induced neurite outgrowth and protein phosphorylation by a newly synthesized selective inhibitor of cyclic AMP-dependent protein kinase, $\mathrm{N}$-[2-(p-bromocinnamylamino) ethyl]-5-isoquinolinesulfonamide (H-89), of PC12D pheochromocytoma cells. J Biol Chem 265: 5267-5272, 1990.

19. Yang SH, Sharrocks AD and Whitmarsh AJ: MAP kinase signalling cascades and transcriptional regulation. Gene 513: $1-13,2013$.

20. Kreideweiss S, Ahlers C, Nordheim A and Rühlmann A: Ca2+-induced p38/SAPK signalling inhibited by the immunosuppressant cyclosporin A in human peripheral blood mononuclear cells. Eur J Biochem 265: 1075-1084, 1999.

21. Chyan YJ, Rawson TY and Wilson SH: Cloning and characterization of a novel member of the human ATF/CREB family: ATF2 deletion, a potential regulator of the human DNA polymerase beta promoter. Gene 312: 117-124, 2003.

22. Faumont N, Le Clorennec C, Teira P, Goormachtigh G, Coll J, Canitrot Y, Cazaux C, Hoffmann JS, Brousset P, Delsol G, et al: Regulation of DNA polymerase beta by the LMP1 oncoprotein of EBV through the nuclear factor-kappaB pathway. Cancer Res 69: 5177-5185, 2009 